\title{
Show me the Money: Pecking Order and Funding Sources for Innovative Firms in Colombia*
}

\author{
Déjame ver el dinero: orden jerárquico y fuentes de financiamiento para empresas innovadoras en Colombia \\ Deixe-me ver o dinheiro: ordem hierárquica e fontes de financiamento para empresas inovadoras na Colômbia
}

\author{
Alberto Méndez-Morales ${ }^{a}$ \\ Universidad Militar Nueva Granada, Colombia \\ edgard.mendez@unimilitar.edu.co \\ ORCID: http://orcid.org/0000-0001-7971-5305
}

DOI: https://doi.org/10.11144/Javeriana.cao32-59.stmpo Redalyc: http://www.redalyc.org/articulo.oa? id=cuadernoss 20561244004

Date received: 06 February 2018

Date accepted: 11 October 2019

\begin{abstract}
:
We analyze the funding sources for innovation activities in Colombia. Our main objective is to identify the type of capital structure followed by firms performing R\&D activities, whether they follow a pecking order (POT) or an altered pecking order capital structure (APOT). We use a multivariate probit methodology and our main result is the fact that innovative companies in Colombia, tend to finance their innovation ventures using a capital structure like the one predicted by the POT. Our results reinforce the fact that innovative companies of underdeveloped countries are, to some extent, different from those of developed countries, and therefore, strategies and policies directed to surpass financial barriers in underdeveloped nations, should be different from the ones designed for developed ones.
\end{abstract}

JEL codes: G20, G32, O30

Keywords: finance of innovation, multivariate probit, Pecking order.

\section{Resumen:}

Indagamos en las fuentes de financiamiento para actividades de innovación en Colombia. El propósito principal es identificar el tipo de estructura de capital que adoptan las empresas que emprenden actividades de I + D, ya sea que esas empresas se ajusten a una estructura de orden jerárquico (POT por sus siglas en inglés) o a una estructura de capital de orden jerárquico alterada. Utilizamos una metodología probit multivariada y nuestro principal resultado es el hecho de que las empresas innovadoras en Colombia muestran la tendencia a financiar sus emprendimientos de innovación a través de una estructura de capital como la que se plantea en el POT. Nuestros resultados refuerzan el hecho de que las empresas innovadoras de los países subdesarrollados son, en cierta medida, diferentes a aquellas de los países desarrollados y, por consiguiente, las estrategias y políticas dirigidas a superar las barreras financieras en las naciones subdesarrolladas deben ser diferentes de aquellas diseñadas para los países desarrollados.

Códigos JEL: G20, G32, O30

Palabras clave: financiamiento de la inovación, multivariate probit, Pecking order.

\section{Resumo:}

Indagamos nas fontes de financiamento para atividades de inovação na Colômbia. O principal objetivo é identificar o tipo de estrutura de capital adotado pelas empresas que empreendem atividades de P\&D, seja que essas empresas estejam em conformidade com uma estrutura hierárquica (POT por suas siglas em inglês) ou com uma estrutura de capital de ordem hierárquica alterada. Utilizamos uma metodologia probit multivariada e nosso principal resultado é o fato de as empresas inovadoras na Colômbia mostrarem a tendência de financiar seus empreendimentos de inovação por meio de uma estrutura de capital como a proposta no POT. Nossos resultados reforçam o fato de que empresas inovadoras em países subdesenvolvidos são, em certa medida, diferentes daquelas dos países desenvolvidos e, portanto, estratégias e políticas destinadas a superar barreiras financeiras em países subdesenvolvidos devem ser diferentes daquelas projetadas para os países desenvolvidos.

Códigos JEL: G20, G32, O30

Palavras-chave: financiamento da inovação, multivariate probit, Pecking order.

\section{Author notes}




\section{INTRODUCTION}

The well-known theory of capital structure introduced for Modigliani \& Miller-M\&M- (1958), proposed that differences in capital sources used for firms to support their investments, have no impact on their value. Basically, this theory suggests that in a market without failures, a firm will be indifferent to all the possible capital sources, because the implicit cost for each of those sources will be equal; i.e., a firm could use cash flow, debt, equity or even venture capital, and the firm value will remain invariant.

Generally, the M\&M theory has been rejected given that corporate and personal taxes affect firm's capital structure; in the same direction, the presence of information asymmetries, agency costs and adverse selection issues, create differences among the cost of diverse firms' funding sources; i.e., firms' decision about the use of one or another capital source could diminish or elevate the cost of that firms' capital, and therefore, the value of the company (Myers, 2001; Myers \& Majluf, 1984).

Given market failures, an influential theory of capital structure based on the existence of those failures was proposed by Myers \& Majluf (1984). This theory, so-called Pecking Order Theory -POT-, suggests that, in presence of information asymmetries and adverse selection failures between firm managers and outside investors, firms will prefer internal over external funding for their ventures. However, if internal resources are scarce, a firm would have to seek external resources, i.e., debt or equity funding. Assuming that in most of the cases, debt is cheaper than equity (because agency costs raise the risk of equity funding), a firm will select debt financing over equity, therefore, when a firm need to finance a new investment, it will select funding sources in a hierarchical order, first internal sources, then debt, and finally equity.

Although the pecking order theory was developed to understand the way firms finance their capital assets, some researchers have focused on the capital structure of intensive R\&D firms, or in the capital structure of high technology startups. Academic results seem to be contradictory: some researchers found that firms finance $R \& D$ and innovation activities as described in the pecking order theory (Bartoloni, 2013; Giudici \& Paleari, 2000; Hummel, Karcher, \& Schultz, 2013; Manigart \& Struyf, 1997; Ullah, Abbas, \& Akbar, 2010), however, some others found evidence of a new form of pecking order (Aghion, Bond, Klemm, \& Marinescu, 2004; Minola, Cassia, \& Criaco, 2013; Sau, 2007; Schäfer, Werwatz, \& Zimmermann, 2004).

This new form of pecking order theory suggests that high tech, innovative or new technology-based firms, strongly use internal resources as a main financial source, just like in the usual pecking order theory; but, in respect to external resources, equity is preferred over debt, because innovative firms cannot access to debt markets. In that sense, some studies have shown that innovative firms tend to be credit-constrained because of moral hazard and adverse selection issues regarding their innovation activities (Bartoloni, 2013; Colombo \& Grilli, 2007; Freel, 2007) and in some cases, debt markets are not willing to leverage innovative ventures because of the long-term focus of those endeavors, the high proportion of intangible assets used, and the uncertainty related with innovation profits. In those cases, a firm with a strong focus on innovation activities, or a high technology firm, will first use cash flow, then equity and debt as a final option (Aghion et al., 2004; Bartoloni, 2013; Minola et al., 2013; Schäfer et al., 2004; Ullah et al., 2010) creating an altered form of pecking order theory -APOT-.

In most of the cases, the evidence about an APOT has been found in developed countries in which firms' possibilities to raise equity are higher than in other types of countries with illiquid capital markets, or in countries in which the venture capital funding is strong compared with underdeveloped countries. In order to raise venture capital or equity from markets, firms need to be supported by a liquid and specialized capital market to provide the necessary conditions for an exit strategy for early venture capitalists (Hall \& Lerner, 2009), this could be an Initial Public Offering-IPO-, or a targeted sell in over the counter-OTC- markets. In that sense, research carried out in developed countries about the way innovative firms fund their ventures could be biased given this selection bias; so, it is possible that the financial behavior of firms in underdeveloped 
countries, with a small and illiquid equity markets (OTC and trading markets), differ from those in developed countries.

This paper attempted to reach three goals. First, to determine the main characteristics of firms' funding innovation with internal resources, bank credit, equity, government grants, and other funding sources in Colombia. Secondly, to find the likelihood for Colombia's firms to fund their R\&D and innovation ventures with those same financial sources. We wanted to determine if, in a developing country like Colombia, the POT or the APOT capital structures are followed by firms to finance their R\&D and innovation activities. Third, we want to understand the behavior of innovation firms in a country like Colombia, given that companies tend to perceive high barriers to innovation of all kinds, and in particular, in the financial field.

This is a novel approach to the financing of innovation given that we are using only data from an anonymized national innovation survey, instead of using data from public-traded firms, that is the usual in related papers; we believe that the use of this data is more realistic given that in developing countries, public traded firms are an exception. Our results reinforce the fact that innovative companies of underdeveloped countries are, to some extent, different from those of developed countries, and therefore, policies directed to surpass financial barriers should be different from the ones designed for those countries.

This paper is structured as follows. The first section includes a review of pertinent literature and a small analysis of financial market development in Colombia and in the countries in which POT and APOT research has been developed. In the second section, data, methodology, and expected results are developed. In the thirth one, the results for the econometric model are described; in fourth section, we developed the main conclusions of the report, and we describe research limitations and future research work related to this topic.

\section{LITERATURE REVIEW}

In 1958, Modigliani and Miller -M\&M- proposed that under equilibrium, given that agents have the possibility of arbitration, the value of a levered and an unlevered firm, would be the same. According to them, "the cut-off point for investment in the firm... will be completely unaffected by the type of security used to finance their investment" (Modigliani \& Miller, 1958, p. 288). The logical conclusion to which this postulate takes us, is that firms could raise money from any given financial source, the cost of capital for each firm will be the same, and all firms will have the same access to capital (Myers, 2001). However, the fact that the M\&M thesis was framed in an equilibrium market without corporate taxes, agency costs, and with symmetric information, has led to the rise of new capital structure theories in which more realistic market characteristics are included.

Tradeoff Theory -TOT- developed by Kraus \& Litzemberg (1973), was built on M\&M propositions and includes the effect of corporate and personal taxes, but also bankruptcy costs; the TOT implicates that there is an optimal point of debt in which managers maximize the value of a levered firm. This can be done by maximizing the debt tax shield and minimizing the bankruptcy costs; over this point, if a firm acquires more debt, the value of the levered firm will be lower than the unlevered one. Even so, firms can choose not to pursue the maximizing point of value through debt, because sometimes they prefer to fund their ventures with other sources like cash flow or equity (Myers, 2001) or because sometimes, those companies do not have enough market power to raise money from external sources, this is the case of most of SMEs.

The Pecking Order Theory -POT- (Myers \& Majluf, 1984), assumes a market in which there are information asymmetries between managers and investors. In this context, the manager's decision to issue equity to finance a new venture, provides information to investors about an overvalued company, because managers only will issue shares (on public or OTC markets) when they can maximize the amount of cash received by the seller. Then, the direct effect of an equity issue in this context is the fall in stock prices. In the same framework, if a firm can use debt or equity to finance their ventures, an investor would understand 
that an equity issue is made by managers to transfer the risk to new stockholders (Because managers cannot transfer risk to lenders given that lender rights are prior to equity holders rights), therefore, investors will understand that equity acquisitions are not a good idea. As a result, the POT claims that firms will prefer internal rather than external sources of finance, because there are no information asymmetries inside the firms; when external sources are needed, firms will prefer debt over equity, i.e., the safest and cheapest sources of money first.

At the same time, although the POT was developed to understand the way that firms of all kinds fund their typical assets, some researchers have focused on the capital structure of intensive R\&D and innovation firms to explore if, for those kinds of companies, the POT is supported.

According to Hall \& Lerner (2009) and Hall, Moncada-Paternò-Castello, Montresor, \& Vezzani (2016), the market failures are stronger for innovative and high technology firms; in the first instance, innovation is riskier and longer-term compared with traditional capital investments. Consequently, the profit rate required by external investors is higher than in other kinds of endeavors because of the uncertainty of the projects. In that sense, one can expect innovative firms to be highly financed by internal funding. At the same time, when innovative firms have to rely on external funding, asymmetric information is a significant issue for those companies; the fact that firms have better information about the real possibilities of their ventures elevates the cost of external funding. To solve this issue, one might think that full revelation of the innovative venture could be a solution, but in that case, the innovator could be imitated by its competition (Hall \& Lerner, 2009). Simultaneously, innovative companies have lower rates of collateral assets to support debt, i.e. the main objective of those firms is to create knowledge embedded in new products or services, and the asset in which firms support this knowledge creation is human capital, that cannot be used as debt collateral, and therefore, it's expected for innovative companies to be credit-constrained because they do not have collateral assets (Colombo \& Grilli, 2007; Freel, 2007).

For these reasons, it is expected that innovative firms tend to prefer internal over external sources to finance their activities. Nevertheless, innovation activities are costly, and therefore, firms tend to raise money externally. However, given that high technology and innovative firms could be credit constrained, some firms will prefer to finance their projects with equity rather than debt, giving room to an altered form of pecking order -APOT-, in which firms prefer internal over external sources, but equity over debt financing, -for a complete description of the Altered Pecking Order phenomena, review the work of Sau (2007).

In this area, research results seem to be contradictory. Some researches found that firms finance their R\&D and innovation activities as described in the POT (Bartoloni, 2013; Giudici \& Paleari, 2000; Hummel et al., 2013; Manigart \& Struyf, 1997; Mina \& Lahr, 2018; Ullah et al., 2010), while others, found evidence of an APOT for firm's intensive on R\&D and innovation activities (Aghion et al., 2004; Audretsch \& Lehmann, 2004; Minola et al., 2013; Schäfer et al., 2004; Ullah et al., 2010). Those differences reinforce the fact that companies not always tend to behave similarly in all economies, and therefore, a policymaker needs to identify how firms conduct related to R\&D financial sources.

For instance, Manigart \& Struyf (1997), working with their own developed survey for 18 Belgium firms, found out that there's evidence of a capital structure under the POT parameters for high technology companies, and that firms tend to have lower proportions of collateral assets in which credit rationing will appear; they worked also with government as a source of finance, finding out that there was little effect of the latter over capital structure of high technology firms. Giudici \& Paleari (2000) used data from 46 high technology Italian SMEs, and employing a direct survey, they concluded that those firms had a capital structure like POT predicts. Also, for Italy, Bartoloni (2013) used a data combination between the Community Innovation Survey -CIS3- and an administrative survey for 2.591 firms between 1.996 and 2.003, and determined that firms follow the POT capital structure characteristics, -for a complete description of the Community Innovation Survey, review Arundel et al. (2008). They also found that the way firms fund innovation depends mainly on specific characteristics such as size, age, localization, or innovative 
behavior. Ullah et al. (2010) found out that in the United Kingdom, firms belonging to the software industry, followed the POT capital structure, and that some firm characteristics such as industrial belonging could define the way firms fund their ventures. Hummel et al. (2013) used data from 171 surveyed SMEs from Germany. They found out that the innovativeness degree of a firm had an impact on the way companies are financed. Also, they confirmed that for that group of firms, their capital structures were like the POT predicts. Lastly, Mina \& Lahr (2018) using data from 1540 companies in the US and 2129 firms in UK, finds that innovation intensity tends to shape how firms finance their innovation ventures, been the most innovative companies more affected by the pecking order capital structure.

On the side of the APOT for innovative and high technology firms, Aghion et al. (2004) used 900 firms from the London Stock Exchange and found that intensive R\&D firms have different financial behaviors than other types of companies, because those firms tend to use more debt than firms with low levels of R\&D expenditures. In the same direction, they found that firms with the highest levels of R\&D expenditure are likeliest to fund ventures with equity than with debt, confirming the existence of an APOT. At the same time, Audretsch \& Lehmann (2004), using data from 341 German traded firms, found out that growing high technology firms tended to privilege external equity over external debt, and that those sources were not complementary, but were substitutes.

In the case of Ullah et al. (2010), although they found that in the United Kingdom the software firms followed a POT pattern, they used data for 42 software firms and 41 biotech firms, showing that biotech firms, have an APOT capital structure, concluding that some industry characteristics could influence the way innovative firms fund their ventures. In the same sense, Minola \& Cassia (2013), working with data from 5,000 firms from the Kauffman Firm Survey, found out that the most innovative firms tended to have an APOT capital structure pattern. However, they also found that firm characteristics tended to define the way they funded R\&D expenditures. In the case of Germany, although they were not working within the APOT framework, Schäfer et al. (2004) used data from 903 firms involved in government innovation programs and found out that firms willing to finance their ventures with equity sources, are the riskier ones, suggesting that when the expected return is high, firms and investors are willing to use shares to finance their projects in detriment of debt funding sources.

One major issue about some of those researches about capital structure, especially the ones supporting an APOT, is the use of data for public-traded firms; is well-known that financial markets in those countries are well-suited for venture capital and equity funding (Hall \& Lerner, 2010; Kerr \& Nanda, 2015), therefore, the fact that those firms are supported by equity is not a surprise. However, those kinds of firms are an exception, especially for underdeveloped countries where capital markets are illiquid, have a low transactional volume, and have a small set of traded firms. At the same time, young high technology firms trade their stocks in public markets only in rare occasions, most of the time, those firms need much time in order to surpass the risky phases of development in order to begin its path on public markets. We believe that those differences in capital markets within countries, are fundamental to understand the results of capital structures inside firms, because, in a country in which capital markets are deep and well organized, the APOT structure will arise as the result of market possibilities, but in countries with smaller and undeveloped markets, the POT structure will be more suited for industrial innovation.

In table 1 it is possible to appreciate those differences for some OECD members like Colombia, Belgium, Italy, Germany, the United Kingdom, and the United States between 2000 and 2009. We used this particular set of countries given that these are the ones related to the literature reviewed in preceding paragraphs; we add the OECD members to develop a comparative context. With table 1 data, it is possible to appreciate that Colombia has an embryonic capital market. Capitalization of listed domestic firms is low compared with OECD, United Kingdom, and the United States. For the years 2008 and 2009, Colombia had higher market capitalization as a percentage of GDP than Belgium, Italy, and Germany. However, this could be a 
consequence of the subprime crisis in developed countries in which Colombia's market grew as a consequence of the inflows of international investment.

TABLE 1

Capital markets of selected countries and the OCDE

\begin{tabular}{|l|c|c|c|c|c|c|c|c|c|c|}
\hline \multicolumn{1}{|c|}{ Market capitalization of listed domestic companies (\% of GDP) } \\
\hline & $\mathbf{2 0 0 0}$ & $\mathbf{2 0 0 1}$ & $\mathbf{2 0 0 2}$ & $\mathbf{2 0 0 3}$ & $\mathbf{2 0 0 4}$ & $\mathbf{2 0 0 5}$ & $\mathbf{2 0 0 6}$ & $\mathbf{2 0 0 7}$ & $\mathbf{2 0 0 8}$ & $\mathbf{2 0 0 9}$ \\
\hline OECD & 108.4 & 94.2 & 75.8 & 89.6 & 95.0 & 99.3 & 112.4 & 110.4 & 58.1 & 81.0 \\
\hline Colombia & - & - & - & - & - & 34.5 & 34.6 & 49.2 & 36.0 & 60.1 \\
\hline Belgium & 76.7 & 69.7 & 49.3 & 54.4 & 73.7 & 74.5 & 96.7 & 81.7 & 32.2 & 53.6 \\
\hline Italy & 67.3 & 45.4 & 37.7 & 39.2 & 43.9 & 43.1 & 52.8 & 48.7 & 21.8 & 30.0 \\
\hline Germany & 65.1 & 54.9 & 33.0 & 43.1 & 42.4 & 42.0 & 54.5 & 61.2 & 29.6 & 37.8 \\
\hline U. Kingdom & 165.7 & 139.9 & 110.5 & 124.8 & 122.5 & 126.4 & 146.1 & 129.5 & 66.9 & \\
\hline U. States & 146.9 & 131.7 & 100.7 & 123.9 & 133.0 & 129.8 & 141.2 & 137.6 & 78.7 & 104.6 \\
\hline \multicolumn{8}{|c|}{ Listed domestic companies, per million inhabitants } \\
\hline OECD & 20.8 & 20.7 & 20.0 & 21.2 & 18.5 & 18.5 & 21.6 & 21.7 & 21.0 & 20.0 \\
\hline Colombia & 1.8 & 2.9 & 2.6 & 2.6 & 2.5 & 2.3 & 2.1 & 2.0 & 2.0 & 1.9 \\
\hline Belgium & 25.9 & 26.7 & 24.8 & 24.1 & 22.6 & 21.2 & 19.4 & 16.5 & 16.0 & 15.3 \\
\hline Italy & 5.2 & 5.2 & 5.2 & 4.7 & 4.7 & 4.7 & 4.9 & 5.2 & 5.0 & 4.9 \\
\hline Germany & 9.0 & 9.1 & 8.7 & 8.3 & 8.0 & 7.9 & 8.0 & 9.3 & 9.0 & 8.6 \\
\hline U. Kingdom & 41.2 & 41.2 & 40.5 & 38.7 & 41.4 & 45.6 & 47.9 & 42.2 & 39.1 & 35.0 \\
\hline U. States & 24.5 & 21.7 & 19.8 & 18.3 & 17.8 & 17.4 & 17.2 & 17.0 & 15.3 & 14.3 \\
\hline \multicolumn{8}{|c|}{ Stocks traded, total value (\% of GDP) } \\
\hline OECD & 160.4 & 118.7 & 91.7 & 83.3 & 91.5 & 112.6 & 134.3 & 177.3 & 166.3 & 127.5 \\
\hline Colombia & 1.2 & 0.8 & 1.1 & 0.9 & 1.8 & 6.5 & 9.6 & 8.3 & 7.4 & 8.5 \\
\hline Belgium & 16.2 & 15.9 & 14.7 & 13.0 & 20.3 & 27.5 & 33.0 & 49.1 & 36.8 & 25.4 \\
\hline Italy & 86.7 & 51.6 & 45.5 & 46.7 & 50.1 & 56.9 & 62.2 & 100.5 & 57.9 & 42.4 \\
\hline Germany & 93.7 & 66.7 & 41.9 & 40.6 & 41.9 & 45.0 & 65.0 & 94.6 & 111.7 & 52.3 \\
\hline U. Kingdom & 117.9 & 123.3 & 62.3 & 64.1 & 70.6 & 71.5 & 106.8 & 132.9 & 97.9 & 121.3 \\
\hline U. States & 289.6 & 196.6 & 155.3 & 139.4 & 155.6 & 197.0 & 220.7 & 296.0 & 321.0 & 237.9 \\
\hline
\end{tabular}

Source: World Bank Databank, author's calculations.

Nevertheless, in 2005 and 2006, the market capitalization of Colombia was low in comparison with those countries. The number of listed firms also showed that Colombia's market is small in comparison with those of developed countries; for instance, Colombia has two firms per million inhabitants listed in the year 2000 compared with 35 in the United Kingdom. Lastly, the total value of stocks traded in the market as a percentage of the GDP was $9.6 \%$ in Colombia's best year, against $220,7 \%$ of the United States in the same year. The point here is that if the development of capital markets is related to the finance sources that innovative firms can use, we expect equity funding for innovative companies to be restricted in developing markets creating an environment in which POT is more likely than APOT structures.

At the same time, researches in which publicly traded firms were used, tended to use a small set of surveyed firms; contrary to this, a great number of firms where used on researches in which Community Innovation Survey -CIS- data were available. For instance, Bartoloni (2013) used data for 2.591 firms based on the CIS for Italy; this survey had access to a more comprehensive set of data about innovation activities, and not only the R\&D firm expenditures, which is the most common innovation proxy used on research with publicly listed companies.

Simultaneously, research using publicly listed firms tend to use a complete set of financial reports of these companies, including profits and losses, cash flows, and balance sheets statements. This because researchers do not have access to data about the financial behavior of firms related directly with R\&D and innovation activities. The problem with the use of full financial reports is that in a majority of cases, researchers only can make assumptions about the financial behavior of firms regarding innovation activities, i.e., financial reports can only give us information about the amounts of debt and equity in a general view, including innovative and non-innovative activities. However, innovation usually does not follow the logic of firms' general activities; so, one can expect that the financial behaviors of firms regarding innovation would be slightly different from the financial reports data. In that case, it could be interesting to have data about the way firms finance their innovation activities and relate that information with the innovative behavior of companies. Unfortunately, it is not common to find this information jointly, because the innovation surveys following the Oslo Manual (OECD, 2005), do not include questions about the financial behaviors of firms.

The present research is a novel effort in the sense that we used data from a national innovation survey, in contrast with other studies using data from publicly traded companies. We believe that the use of this data is more realistic, given that in developing countries, public traded firms are an exception. As we know, only one 
effort has been developed to use this type of information to determine the way firms finance their innovation activities. It was developed by Sierra, Malaver, \& Vargas (2009) for the Bogotá (Colombia) region; in this research, they found that internal resources and national banking, followed by government grants, were the main funding sources for innovative firms. However, the inexistence of an equity source in data does not allow them to probe the existence of a POT or an APOT capital structure. In this research, we tried to determine, in first instance, if the main characteristics of firms using the different funding sources, could define the way that firms finance their innovative efforts, and second, corroborate if Colombia's innovative firms followed the POT or APOT capital structure.

\section{DATA, METHODOLOGY AND EXPECTED RESULTS}

Colombia's EDIT ${ }^{1}$ survey follows the general guidelines of the European Community Innovation Survey; however, this survey has a particular chapter in which firms are asked about the funding sources used for innovation activities. Among the sources, the EDIT includes are internal resources, bank debt, equity, government funds, and others. ${ }^{2}$ Given that in the reviewed literature one cannot find a source of information including data about innovation activities by one side, and data about the way firms finance those innovation activities on the other, the EDIT survey is a special case that can be reviewed to understand the way firms' funds innovation-related activities, specially, if one is interested in the behaviors of innovation companies in underdeveloped countries.

We used the 2007-2008 EDIT results, that includes 7.683 manufacture firms, of which $67.3 \%$ are firms between 1 and less than 50 employees, $25.1 \%$ are firms with at least 50 and 250 employees, and $7.6 \%$ are firms with more than 250 workers. However, we only used companies with positive expenditures on R\&D and innovation, and we restrict data of firms with less than ten employees; therefore, our final sample is 2.621 firms. In that sample, $16.3 \%$ are big firms with more than 250 employees, $39.9 \%$ have between 50 and 250 employees, and $43.9 \%$ have between 10 and 50 workers.

Firms in our sample were asked about the origin of funds used to support R\&D and innovation activities; therefore, we characterized the innovation funding sources for the sample. We used dummy $(1 ; 0)$ variables to identify when a firm was using or not using a specific funding source. As we can see in table 2 , internal funding was the most used resource in all firms, followed by banks. Specially drew our attention to the fact that equity is not the third most used source of funding; government grants and other sources represented $3.1 \%$ and $3.2 \%$ against $2.0 \%$ of equity. Medium-size firms were the ones with the most frequent use of equity; however, for this type of firm, the sum of government grants, and other sources represented almost three times the frequency of use against equity. Large companies were the ones that use most frequently internal resources, banks, and government grants.

TABLE 2

Funding source used by firm size

\begin{tabular}{|l|l|c|c|c|c|c|}
\hline Size & $\#$ & $\begin{array}{c}\text { Internal funds } \\
\mathbf{( \% )}\end{array}$ & $\begin{array}{c}\text { Banks } \\
(\mathbf{\% )}\end{array}$ & $\begin{array}{c}\text { Equity } \\
(\mathbf{\%})\end{array}$ & $\begin{array}{c}\text { Public grants } \\
\mathbf{( \% )}\end{array}$ & $\begin{array}{c}\text { Others* } \\
\mathbf{( \% )}\end{array}$ \\
\hline All Sample & 2.621 & 87.8 & 29.7 & 2.0 & 3.1 & 3.2 \\
\hline Small $>10 ;<50$ & 1.150 & 87.5 & 26.8 & 1.8 & 1.7 & 2.9 \\
\hline Medium $>=50 ;<=250$ & 1.045 & 87.5 & 31.7 & 2.4 & 3.4 & 3.8 \\
\hline SMEs $(>10 ;<=250)$ & 2.195 & 87.5 & 29.1 & 2.1 & 2.5 & 3.3 \\
\hline Large $(>250)$ & 426 & 89.7 & 32.4 & 1.4 & 6.1 & 2.3 \\
\hline
\end{tabular}

* Includes international cooperation, economic group and other non-related firms. Source: EDIT 2007-2008.

In table 3 the tetrachoric correlations for the dummy variables of funding sources are shown; it seems evident that decisions for taking one type or other funding source are correlated, e.g., the use of internal sources is negatively correlated with banks, equity, public grants, and other type of funds. Bank funding is positively correlated with equity and other sources, etc. In this case, one can argue that this is a logical 
outcome; firms do not use an exclusive funding source, but a combination of them, so a specific company can use internal funding, banks, and government funding at the same time, and all the possible combinations of those sources. In the same sense, a firm's decision to use one of the funding sources can be affected by the likelihood they have access to another funding source. In that direction, we also performed a multivariate test for covariance to determine if funding sources are jointly decided by firms, specifically, we used a likelihood ratio test to review if the variance-covariance matrix is a diagonal one or if the matrix contains significant covariance among variables. The test results showed that funding sources are strongly related to them (The adjusted $L R$ chi $^{2}$ was 754.02 and prob $>$ chi $\left.^{2}=0.0000\right)$. This result had implications in the econometric strategy used for our research. If the funding sources fluctuated jointly, it was necessary to use a multivariate approach. Therefore, and given that we are using dummy variables for funding sources, we decided to use a multivariate probit model following the strategy of Cappellari \& Jenkins (2003).

TABLE 3

Correlations of funding sources

\begin{tabular}{|l|l|l|l|l|l|}
\hline & Internal & Bank & Equity & Public & $\begin{array}{c}\text { Other } \\
\text { sources }\end{array}$ \\
\hline Internal & 1 & & & & \\
\hline Bank & $-0.7743^{*}$ & 1 & & & \\
\hline Equity & $-0.5505^{*}$ & $0.1813^{*}$ & 1 & & \\
\hline Public & $-0.1870^{*}$ & & & 1 & \\
\hline Other sources ${ }^{*+}$ & $-0.3006^{*}$ & $0.1425^{*}$ & & $0.2389^{*}$ & 1 \\
\hline
\end{tabular}
** Only correlation with 5\% significance level are shown.
Source: EDIT 2007-2008.

The variables used in the model are summarized in table 4. We included five dependent dummy variables to cover all the funding sources used by firms in order to finance their $\mathrm{R} \& \mathrm{D}$ and innovation activities. The independent variables included can be divided into two groups, the expense vector $\left(X_{j}\right)$ and the firm characteristics vector $\left(Z_{j}\right)$. The expense vector includes four variables counting for one of the firm had an expense of that type (internal or external R\&D, intangible innovation, tangible innovation, and biotechnology expenses), and 0 otherwise. The firm characteristics vector included a log of the firm size, a dummy variable for capital origin of firms, a dummy variable counting if a firm is innovative or not, a variable equal 1 if firms have strong financial barriers perception, a sectorial dummy variable for firms of high technology industry, and lastly, a proxy variable for innovative revenues.

TABLE 4

Variables used in the multivariate probit models

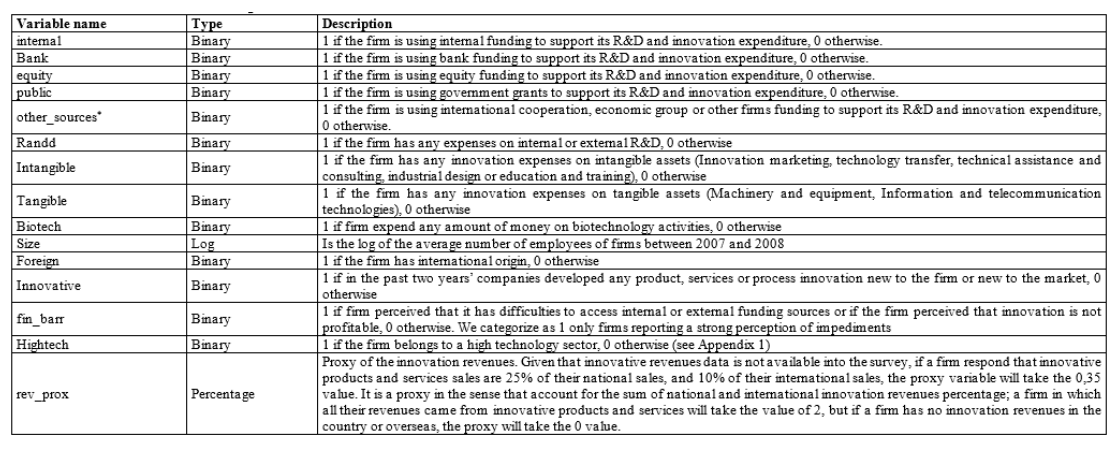

${ }^{*}$ Includes international cooperation, economic group, and other non-related firms. Source: Own elaboration.

The multivariate probit model (Green, 2003) could be described as:

$$
Y_{i, j}=\left\{\begin{array}{c}
1 \text { if } Y_{i}^{*}>0 \\
0 \text { otherwise }
\end{array}\right.
$$


in which $i$ are the five different funding sources described in table 4 , and $j$ are each one of the firms included in our sample with,

$$
\begin{aligned}
& Y_{1}^{*}=X_{j} \beta_{1,1}+Z_{j} \beta_{2,1}+\varepsilon_{1} \\
& Y_{2}^{*}=X_{j} \beta_{1,2}+Z_{j} \beta_{2,2}+\varepsilon_{2} \\
& Y_{3}^{*}=X_{j} \beta_{1,3}+Z_{j} \beta_{2,3}+\varepsilon_{3} \\
& Y_{4}^{*}=X_{j} \beta_{1,4}+Z_{j} \beta_{2,4}+\varepsilon_{4} \\
& Y_{5}^{*}=X_{j} \beta_{1,5}+Z_{j} \beta_{2,5}+\varepsilon_{5}
\end{aligned}
$$

$Y_{i}^{*}, X_{j}$ is the expense vector, and $Z_{j}$ is the firm characteristics vector. And with,

$$
\left[\begin{array}{l}
\varepsilon_{1} \\
\varepsilon_{2} \\
\varepsilon_{3} \\
\varepsilon_{4} \\
\varepsilon_{5}
\end{array}\right] \mid X, Z \sim N\left(\left[\begin{array}{l}
0 \\
0 \\
0 \\
0 \\
0
\end{array}\right],\left[\begin{array}{ccccc}
1 & \rho_{1,2} & \rho_{1,3} & \rho_{1,4} & \rho_{1,5} \\
\rho_{1,2} & 1 & \rho_{2,3} & \rho_{2,4} & \rho_{2,5} \\
\rho_{1,3} & \rho_{2,3} & 1 & \rho_{3,4} & \rho_{3,5} \\
\rho_{1,4} & \rho_{2,4} & \rho_{3,4} & 1 & \rho_{4,5} \\
\rho_{1,5} & \rho_{2,5} & \rho_{3,5} & \rho_{4,5} & 1
\end{array}\right]\right)
$$

Along with the reviewed literature (Aghion et al., 2004; Bartoloni, 2013; Hummel et al., 2013; Minola et al., 2013; Ullah et al., 2010), we expected that the firm characteristic vector $\left(Z_{i}\right)$, determines the way firms use funding sources, i.e., characteristics like size, innovation results, capital origin, industry, revenues related with innovation, and the perception of financial barriers, influence the use of innovation financial sources. In the same direction, we expect the expense vector $\left(\mathrm{X}_{\mathrm{i}}\right)$ to be related with the funding sources used by firms, i.e., if a firm made an expenditure on $\mathrm{R} \& \mathrm{D}$, biotechnology, tangible or intangible innovation, this could determine the access to those financial sources, Manigart \& Struyf (1997). As we pointed in the literature review, Aghion et al. (2004) found that intensive R\&D firms tended to behave differently from those non-R\&D intensive firms regarding their funding sources.

To determinate if innovative firms tended to follow a POT or an APOT capital structure, we determined the marginal predicted probabilities of firms to use internal, bank, equity, public grants, or other sources using the Cappellari \& Jenkins (2003) strategy. We expected that in Colombia, firms tended to follow the POT structure, given that in underdeveloped countries firms do not have easy access to equity markets, as posted in the literature review, and shown in table 1. So, we expected that firms tended to use internal sources in higher proportion, followed by banks, and then equity sources; at the same time, related to the use of public grants and other sources, we predicted probabilities would be lower than internal and bank sources. We were also interested in changing the subsamples of firms to determinate if some sets of firms had different capital structures or had the highest likelihoods of being financed by some of the funding sources. Consequently, we ran the same econometric approach for SME's, big firms, innovative companies, and firms with lower and higher R\&D and innovation expenditures. 


\section{RESULTS}

\section{Results from the full sample}

In table 5, we present the results of the multivariate probit model in which we included all the 2.621 firms from the sample. These results show that firms with positive expenditure in $\mathrm{R} \& \mathrm{D}$ (randd) and firms with expenditures on intangible assets (intangible) tend to finance innovation ventures mostly with their resources. As it was shown in the literature review section, firms facing higher information asymmetries, tended to use internal resources because the external financing is costly for them. In the cases of intensive R\&D firms, the long-term nature of their projects, and the uncertainty of future profits, elevates the cost of external funding. In the same direction, firms strongly investing in intangible assets cannot provide guarantees of future payments in the case of bank access, making companies rely mainly on internal funds.

TABLE 5

MPR, funding sources of R\&D\&i

\begin{tabular}{|l|l|l|l|l|l|}
\hline \multicolumn{1}{|c|}{ Variable } & internal & \multicolumn{1}{c|}{ bank } & \multicolumn{1}{c|}{ equity } & \multicolumn{1}{c|}{ public } & other sources \\
\hline Randd & $0.276^{*+}$ & 0.056 & -0.06 & $0.229^{*}$ & 0.144 \\
\hline Biotech & -0.046 & -0.116 & 0.205 & -0.124 & -0.284 \\
\hline intangible & $0.332^{*+*}$ & 0.006 & $0.298^{*}$ & $0.273^{*}$ & 0.092 \\
\hline tangible & -0.217 & $1.024^{*+*}$ & 0.011 & 0.176 & -0.002 \\
\hline Size & -0.038 & $0.089^{*+*}$ & -0.016 & $0.172^{*+*}$ & -0.006 \\
\hline Foreign & 0.203 & $-0.327^{*+*}$ & -0.268 & -0.116 & 0.092 \\
\hline innovative & -0.075 & $0.448^{*+*}$ & 0.207 & -0.112 & -0.12 \\
\hline fin_barr & -0.115 & $0.238^{*+*}$ & 0.181 & 0.075 & 0.063 \\
\hline hightech & 0.353 & $-0.382^{*}$ & -0.27 & 0.09 & -0.053 \\
\hline rev_prox & -0.027 & 0.021 & 0.062 & -0.019 & 0.037 \\
\hline & $1.511^{*+*}$ & $-2.466^{*+*}$ & $-2.647^{*+*}$ & $-2.941^{*+*}$ & $-1.921^{*+*}$ \\
\hline Predicted Prob. & 0.8802 & 0.2989 & 0.0200 & 0.0309 & 0.0314 \\
\hline $\mathrm{N}$ & \multicolumn{5}{|c|}{2621} \\
\hline Prob>Chi 2 & \multicolumn{5}{|c|}{0.0000} \\
\hline
\end{tabular}

Notes: Multivariate Probit regression. Includes the complete sample. Firms with more than ten employees and with R\&D\&i expenses in the 2007-2008 period.

${ }^{*}$ P. $<0.05$

${ }^{* *} \mathrm{P} .<0.01$

${ }^{* * *}$ P. $<0.001$

Source: Own elaboration.

We were expecting that firm characteristics were determinant to the use of internal funds. For example, small firms tended to be riskier than bigger firms, and therefore, we expected a negative statistical relationship between internal funds and size. However, size, innovation revenues, or innovation, seem to be irrelevant in the case of internal sources. It appears that firms' characteristics do not determine the use of internal funds after being controlled by the type of spending made by firms.

Tangible assets (equipment and machinery, etc.) are relevant for bank funding; therefore in the case of debt, the collateral capability of firms is fundamental. Related with the firm characteristics vector, bigger firms tend to use more banks, maybe this is caused because their expected cash flows and amount of total assets are higher, and this allows those firms to have easier access to bank funding. In the same direction, innovative firms tend to have more access to bank funding, a possible explanation is that these firms could prove to banks their projects could be successfully finished, or because those types of firms are more active in the search for external funding. However, this aspect has to be researched deeply in the future.

At the same time, firms facing financial barriers, i.e., perceiving a strong difficulty finding internal or external funding, tend to have more banking access; although this result seems to be counterintuitive, there is a strong background of literature supporting that innovation, and barriers can be viewed as firms' experience measure on innovative markets (Arundel, 1997; Baldwin \& Lin, 2002; D’Este, Iammarino, Savona, \& von Tunzelmann, 2012; Iammarino, Sanna-Randaccio, \& Savona, 2009), so this result can be viewed as if companies having strong financial barriers were the ones making higher efforts to access bank loans because they know innovative and financial markets better than other firms. 
Firms belonging to high technology industries seemed to be credit constrained. i.e., there is a negative relationship between those industries and bank funding. As was established by Giudici \& Paleari, (2000), it seems that banks restrict the number of loans to high technology firms because banks are not capable to evaluate those kinds of ventures; this is, the market imperfections are stronger for firms in high technology industries. This last result is related to the facts exposed by Hall \& Lerner (2009).

At the same time, foreign capital firms seem to be negative related with bank funding; the fact that these types of firms could have access to the financial branch of their international headquarters, possibly decreased the need to access bank loans. At this point, we tried to run a regression separating group funding sources form an "other sources" variable, trying to determinate if foreign firms used group sources in higher proportions. However, the result was not significant.

The use of equity sources is related to intangible assets expenditure. As we posted before, firms with intangible expenses were also prone to use internal sources, and firms with tangible assets were likely to use banks. The fact that firms with intangible assets expenditure used in higher proportions internal and equity sources, could be a clue for a possible existence of an APOT structure for these types of firms. However, as we can see with the marginal probabilities, this is not the case. In the case of Colombia, the inexistence of a deep stock market could be the cause of this result, and as it was developed in section 3, in countries in which those markets are strong, internal founds and equity are more used than debt financing.

Results for public grant funding show that in Colombia's case, this type of funding is not closing the gap between SMEs and big companies; bigger firms, that in theory are the ones confronting less market failures, are likeliest to use government grants. At the same time, firms investing in $R \& D$ and intangible assets are likeliest to use public grants. In the case of other sources, we found that no independent variables were significantly related to those sources.

To understand if innovative firms in Colombia follow a POT or an APOT capital structure, we calculated marginal probabilities for each of the dependent variables of the multivariate model. As seen in table 5 , the firm's likelihood to use internal funding is $88 \%$, followed by banks with $30 \%$, other sources $3.1 \%$, public grants $3.1 \%$, and finally equity funding with a $2.0 \%$ probability. Firms tended to follow a POT capital structure with little likelihood of using equity sources.

Firms use internal resources in higher proportion mainly because the market failures elevate the external cost of funding; then, if internal resources are not enough to finance their ventures, firms have to look for external resources. In that direction, bank funding is vital for firms even when it is costly, and public and other sources are more likely to be used than equity. Our explanation for the latter result is that in underdeveloped countries, the liquidity and access to capital markets are inferior. In that sense, companies would prefer to use equity over banks in some cases and present an APOT capital structure, however, the fact that the capital market is illiquid and small (table 1), does not allow firms to access equity funds leaving companies with a POT capital structure in which public and other funding sources are better suited than equity sources for innovative ventures.

\section{Sub-sample results}

In order to perform a robustness check, we decided to divide the sample into some subsamples. In the same sense, we were interested in determining if some sets of firms have different probabilities of being funded by diverse financial sources included in the survey.

First, we used a subsample of SMEs, and the results remained unchanged, as can be seen in table 6, a firm likelihood to be financed with internal funds, banks, equity, and other sources remained practically unaltered. However, there was a slight difference in the probability of being financed by public grants from $3.1 \%$ for the complete sample against $2.5 \%$ of SMEs, so it can be seen that small firms were, to some extent, constrained by public grants. We also used a subsample for big firms; however, it cannot be said that regression 
coefficients were different from zero. For this reason, the marginal probabilities had to be interpreted with caution; still, the fact that the likelihood of big firms being funded with public grants was more than two times the likelihood of small firms, could reinforce the fact that SMEs had limited access to public funds. In the same direction, with a probability of $33 \%$, it seems that big firms had more access to bank funding, against $30 \%$ of SMEs.

TABLE 6

MPR for SMEs and big firms

\begin{tabular}{|c|c|c|c|c|c|}
\hline \multicolumn{6}{|c|}{ Sub-sample of SME Firms (10-249 employees) } \\
\hline & internal & bank & equity & public & other sources \\
\hline randd & $0.259^{\text {"* }}$ & 0.106 & 0.047 & $0.338^{* *}$ & 0.225 \\
\hline biotech & 0.006 & -0.149 & 0.104 & -0.319 & -0.244 \\
\hline intangible & $0.303^{* * *}$ & 0.05 & $0.336^{*}$ & $0.312^{*}$ & 0.14 \\
\hline tangible & \begin{tabular}{|l|l|l|l}
-0.197 \\
\end{tabular} & $1.03 \mathrm{~s}^{\mathrm{**}}$ & 0.049 & 0.292 & 0.071 \\
\hline size & -0.029 & $0.087^{*}$ & -0.021 & $0.184^{*}$ & 0.072 \\
\hline foreign & 0.284 & $-0.434^{\text {+** }}$ & -0.29 & -0.371 & 0.191 \\
\hline innovative & -0.094 & $0.551^{\text {w* }}$ & 0.225 & -0.104 & -0.143 \\
\hline fin barr & -0.077 & $0.225^{\mathrm{w*}}$ & 0.215 & 0.107 & 0.064 \\
\hline hightech & 0.29 & $-0.426^{* *}$ & -0.195 & 0.092 & -0.008 \\
\hline rev_prox & -0.025 & 0.021 & 0.043 & -0.038 & 0.026 \\
\hline cons & $1.444^{\text {w** }}$ & $-2.563^{\text {w** }}$ & $-2.660^{* * *}$ & $-3.106^{* * *}$ & $-2.284^{\cdots *}$ \\
\hline Predicted Prob. & 0.8771 & 0.2952 & 0.0217 & 0.0250 & 0.0332 \\
\hline $\mathrm{N}$ & \multicolumn{5}{|c|}{2195} \\
\hline Prob $>$ Chi 2 & & & 0.00 & & \\
\hline \multicolumn{6}{|c|}{ Sub-sample of big firms (250 or more } \\
\hline Variables & internal & bank & equity & public & other sources \\
\hline randd & 0.274 & -0.099 & -0.634 & 0.000 & -0.109 \\
\hline biotech & -0.382 & -0.017 & $0.822 *$ & 0.262 & -3.473 \\
\hline intangible & 0.347 & -0.12 & -0.066 & 0.079 & -0.251 \\
\hline tangible & -0.115 & $0.880^{*}$ & 3.688 & 0.016 & -0.647 \\
\hline size & -0.199 & 0.094 & 0.36 & 0.108 & 0.19 \\
\hline foreign & 0.116 & $-0.297^{*}$ & -0.213 & 0.076 & -0.216 \\
\hline innovative & -0.156 & 0.244 & 2.781 & -0.153 & 3.082 \\
\hline fin_barr & -0.284 & $0.291^{*}$ & -0.011 & -0.046 & 0.016 \\
\hline hightech & 3.882 & -0.369 & -3.692 & 0.059 & -4.149 \\
\hline rev_prox & -0.014 & 0.021 & 0.153 & 0.054 & 0.089 \\
\hline cons & $2.674^{* *}$ & $-2.111^{* \prime}$ & -11.339 & $-2.343^{*}$ & -5.532 \\
\hline Predicted Prob. & 0.8979 & 0.3297 & 0.0139 & 0.0613 & 0.0256 \\
\hline $\mathrm{N}$ & \multicolumn{5}{|c|}{426} \\
\hline Prob $>$ Chi 2 & \multicolumn{5}{|c|}{0.3996} \\
\hline
\end{tabular}

Notes: Multivariate Probit regression. Includes firms with R\&D\&i expenses in the 2007-2008 period.

$$
\begin{aligned}
{ }^{*} \mathrm{P} . & <0.05 \\
{ }^{* *} \mathrm{P} . & <0.01 \\
{ }^{* * *} \mathrm{P} . & <0.001
\end{aligned}
$$

Source: Own elaboration.

We also performed a regression for the subsample of innovative firms (table 7). The results were quite similar; however, the bank access to innovative firms was slightly higher than the total sample. The probability for innovative firms to be funded by banks was $31.5 \%$ against $30 \%$ of the complete sample. Those results are aligned with the ones of Hummel et al. (2013), firm innovativeness is related to financial sources, and most innovative firms are more affected by pecking order capital structure.

TABLE 7

MPR for innovative firms

\begin{tabular}{|l|l|l|l|l|l|}
\hline \multicolumn{1}{|c|}{ Variables } & \multicolumn{1}{c|}{ internal } & \multicolumn{1}{c|}{ bank } & \multicolumn{1}{c|}{ equity } & \multicolumn{1}{c|}{ public } & \multicolumn{1}{c|}{ other sources } \\
\hline randd & $0.308^{* * *}$ & 0.053 & -0.104 & $0.259^{*}$ & 0.14 \\
\hline biotech & -0.025 & -0.117 & 0.206 & -0.135 & -0.312 \\
\hline intangible & $0.355^{* * *}$ & -0.008 & $0.271^{*}$ & $0.243^{*}$ & 0.106 \\
\hline tangible & -0.128 & $1.031^{* * *}$ & -0.096 & 0.143 & 0.021 \\
\hline size & -0.021 & $0.065^{* *}$ & -0.02 & $0.166^{* *}$ & -0.016 \\
\hline foreign & 0.163 & $-0.324^{* * *}$ & -0.22 & -0.155 & 0.154 \\
\hline innovative & & & & & \\
\hline fin_barr & -0.105 & $0.242^{* * *}$ & 0.17 & 0.05 & 0.069 \\
\hline hightech & 0.317 & $-0.420^{* *}$ & -0.31 & 0.093 & -0.082 \\
\hline rev_prox & -0.028 & 0.022 & 0.064 & -0.017 & 0.037 \\
\hline cons & $1.258^{* * *}$ & $-1.914^{* * *}$ & $-2.296^{* * *}$ & $-2.973^{* * *}$ & $-2.040^{* * *}$ \\
\hline Predicted Prob. & 0.8771 & 0.3147 & 0.0208 & 0.0303 & 0.0313 \\
\hline N & \multicolumn{5}{|c|}{2413} \\
\hline Prob>Chi2 & \multicolumn{5}{|c|}{0.0000} \\
\hline
\end{tabular}

Notes: Multivariate Probit regression. Includes firms with R\&D\&i expenses in the 2007-2008 period

${ }^{*}$ P. $<0.05$

${ }^{* *} \mathrm{P} .<0.01$

$$
\text { *** P. }<0.001
$$

Source: Own elaboration. 
We executed the same multivariate probit regression in the case of firms using tangible and intangible assets. Our results are aligned with those found by Manigart \& Struyf (1997), and can be seen in table 8. In the case of firms with tangible assets, results for the independent variables were the same as in the case of the complete sample, however, the probability of bank access was slightly higher for firms expending on tangible assets with a $32 \%$ against $30 \%$ of the full sample. It seems that firms with more tangible assets, and therefore more collateral, could have more access to bank loans. In the case of intangible assets, the results showed that there was a higher probability for firms to use internal funds with a $92 \%$ against the $88 \%$ of the complete sample, or the $87 \%$ of the firms with tangible expenses.

TABLE 8

MPR. Firms with tangible and intangible assets expenses

\begin{tabular}{|c|c|c|c|c|c|}
\hline \multicolumn{6}{|c|}{ Firms with tangible assets expenses (tangible $=1$ ) } \\
\hline Variables & internal & bank & equity & Public & other sources \\
\hline randd & $0.288^{* *}$ & 0.037 & -0.134 & $0.244^{*}$ & 0.177 \\
\hline biotech & -0.033 & -0.087 & 0.218 & -0.112 & -0.277 \\
\hline intangible & $0.344^{*+*}$ & 0.016 & $0.354 * *$ & $0.245^{*}$ & 0.064 \\
\hline \multicolumn{6}{|l|}{ tangible } \\
\hline size & -0.033 & $0.076^{* *}$ & -0.035 & $0.169^{* * *}$ & -0.007 \\
\hline foreign & 0.244 & $-0.330^{* * *}$ & -0.361 & -0.141 & 0.042 \\
\hline innovative & -0.017 & $0.497^{* * *}$ & 0.089 & -0.158 & -0.051 \\
\hline fin barr & -0.109 & $0.233^{*+*}$ & 0.181 & 0.07 & 0.02 \\
\hline hightech & 0.283 & $-0.343^{*}$ & -0.261 & 0.011 & -0.021 \\
\hline rev prox & -0.029 & 0.02 & 0.06 & -0.006 & 0.026 \\
\hline cons & $1.213^{* * *}$ & $-1.426^{* * *}$ & $-2.447^{* * *}$ & $-2.727^{* * *}$ & $-1.922^{* * *}$ \\
\hline Predicted Prob. & 0.8749 & 0.3235 & 0.0201 & 0.0309 & 0.0311 \\
\hline $\mathrm{N}$ & \multicolumn{5}{|c|}{2388} \\
\hline Prob $>$ Chi 2 & \multicolumn{5}{|c|}{$\begin{array}{r}0.0000 \\
\end{array}$} \\
\hline \multicolumn{6}{|c|}{ Firms with intangible assets expenses (intangible $=1$ ) } \\
\hline & internal & bank & equity & Public & other sources \\
\hline randd & $0.243^{*}$ & 0.106 & -0.254 & $0.261^{*}$ & $0.298 *$ \\
\hline biotech & -0.05 & -0.035 & 0.303 & -0.036 & -0.305 \\
\hline \multicolumn{6}{|l|}{ intangible } \\
\hline tangible & -0.176 & $1.078^{* * *}$ & 0.299 & 0.188 & -0.143 \\
\hline size & -0.017 & 0.061 & -0.07 & $0.112^{*}$ & -0.086 \\
\hline foreign & 0.117 & $-0.392^{* *}$ & -0.241 & -0.026 & 0.231 \\
\hline innovative & 0.217 & $0.390^{*}$ & -0.245 & -0.164 & -0.026 \\
\hline fin_barr & -0.108 & $0.280^{* * *}$ & 0.119 & 0.028 & 0.16 \\
\hline hightech & 0.291 & -0.366 & -0.201 & 0.042 & -0.181 \\
\hline rev prox & $-0.061^{*}$ & $0.042^{*}$ & $0.147^{* *}$ & -0.003 & 0.066 \\
\hline cons & $1.576^{* * *}$ & $-2.448^{* * *}$ & $-2.119^{* * 4}$ & $-2.388^{* 4 *}$ & $-1.675^{* * *}$ \\
\hline Predicted Prob. & 0.9204 & 0.3016 & 0.0268 & 0.0430 & 0.0379 \\
\hline $\mathrm{N}$ & \multicolumn{5}{|c|}{1350} \\
\hline Prob $>$ Chi 2 & \multicolumn{5}{|c|}{0.0000} \\
\hline
\end{tabular}

Notes: Multivariate Probit regression. Includes firms with R\&D\&i expenses in the 2007-2008 period.

$$
\begin{gathered}
{ }^{*} \text { P. }<0.05 \\
{ }^{* *} 0.01
\end{gathered}
$$$$
\text { *** P. }<0.001
$$

Source: Own elaboration.

Finally, we divided the sample between firms with higher and lower amounts of R\&D expenses; in this case, we used the log of the expense in R\&D by employee to divide the sample in the above-average firms and below-average firms. The results can be seen in Table 9. Firms with higher expenditure in R\&D seemed to have a lower likelihood of using internal funds than in the complete sample. At the same time, the probability of those firms to use bank funding increased in large proportion with $41 \%$ against $30 \%$ of the complete sample. 
TABLE 9

MPR. Firms above and below the R\&D expenditure average

\begin{tabular}{|c|c|c|c|c|c|}
\hline \multicolumn{6}{|c|}{ Firms above the average of $R \& D$ expenditure } \\
\hline Variables & internal & bank & equity & public & other sources \\
\hline Randd & $0.348^{* *}$ & 0.03 & -0.311 & 0.14 & 0.029 \\
\hline Biotech & 0.02 & $-0.281^{*+}$ & 0.088 & -0.229 & -0.319 \\
\hline Intangible & $0.471^{* \cdots *}$ & $-0.182^{*}$ & $0.442^{*}$ & 0.227 & -0.076 \\
\hline Tangible & 0.065 & $0.876^{+* *}$ & 0.034 & 0.051 & -0.306 \\
\hline Size & 0.014 & 0.026 & -0.072 & $0.155^{* *}$ & -0.087 \\
\hline Foreign & 0.152 & $-0.373^{*+\cdots}$ & -0.014 & -0.153 & 0.199 \\
\hline Innovative & -0.151 & 0.279 & 3.266 & 0.052 & 0.037 \\
\hline fin barr & $-0.195^{*}$ & $0.298^{* * *}$ & 0.023 & 0.102 & 0.05 \\
\hline High-tech & 0.336 & $-0.537^{* *}$ & -3.569 & 0.125 & -0.034 \\
\hline rev_prox & -0.025 & 0.017 & 0.075 & -0.015 & 0.02 \\
\hline cons & $0.903^{*}$ & $-1.493^{*+*}$ & -5.435 & $-2.711^{*+*}$ & $-1.140^{*}$ \\
\hline Predicted Prob. & 0.8529 & 0.4124 & 0.0213 & 0.0443 & 0.0408 \\
\hline $\mathrm{N}$ & \multicolumn{5}{|c|}{1375} \\
\hline Prob $>$ Chi 2 & \multicolumn{5}{|c|}{0.0000} \\
\hline \multicolumn{6}{|c|}{ Firms below the average of R\&D expenditure } \\
\hline Variables & internal & bank & equity & public & other sources \\
\hline Randd & 0.176 & 0.055 & 0.175 & $0.409 *$ & $0.392^{*}$ \\
\hline Biotech & -0.039 & -0.014 & 0.397 & -0.137 & -0.646 \\
\hline intangible & 0.22 & 0.05 & 0.095 & 0.173 & 0.341 \\
\hline tangible & -0.19 & $0.771^{* * *}$ & 0.042 & 0.054 & 0.103 \\
\hline Size & $-0.113^{*}$ & $0.177^{* * *}$ & 0.054 & $0.176^{*}$ & 0.143 \\
\hline Foreign & 0.399 & $-0.499^{* *}$ & -3.348 & -0.162 & -0.267 \\
\hline innovative & 0.064 & $0.421^{*}$ & 0.014 & -0.353 & -0.39 \\
\hline fin barr & 0.016 & 0.155 & $0.540^{*}$ & -0.006 & 0.069 \\
\hline hightech & 0.374 & -0.165 & 0.067 & 0.093 & -0.192 \\
\hline rev_prox & -0.019 & 0.022 & 0.088 & \begin{tabular}{|l|}
-0.031 \\
\end{tabular} & \begin{tabular}{|l|l|}
0.07 \\
\end{tabular} \\
\hline cons & $1.805^{* * * *}$ & $-2.914^{* * *}$ & $-3.077^{\text {tw* }}$ & $-2.820^{* * * *}$ & $-2.849^{\text {w***}}$ \\
\hline Predicted Prob. & \begin{tabular}{|l|}
0.9104 \\
\end{tabular} & 0.1743 & \begin{tabular}{|l|}
0.0202 \\
\end{tabular} & 0.0158 & 0.0219 \\
\hline $\mathrm{N}$ & \multicolumn{5}{|c|}{1246} \\
\hline Prob $>$ Chi 2 & \multicolumn{5}{|c|}{0.0000} \\
\hline
\end{tabular}

Notes: Multivariate Probit regression. Includes firms with R\&D\&i expenses in the 2007-2008 period. R\&D expenditure average was calculated for the log of the R\&D expenditure by employee. ${ }^{*}$ P. $<0.05$

${ }^{* *} 0.01$

*** 0.001

Source: Own elaboration.

In the case of firms with lower R\&D expenses, we found that there is a $91 \%$ change for a firm to use internal funds, against $85 \%$ of higher R\&D firms, and $88 \%$ of the complete sample; this means that firms with less R\&D expenses, tended to use more internal funding. At the same time, firms with lower R\&D expenses had a radically lower probability of using bank loans, with $17 \%$ against $41 \%$ of their counterparts, i.e., firms with lower amounts of R\&D tended to use more internal funding and fewer bank loans.

In the case of Aghion et al. (2004), and Minola \& Cassia (2013), they found that the use of equity arises for firms with higher R\&D, however, in our case, we cannot support that result. The probability of a firm to use equity was not affected by the amount of $\mathrm{R} \& \mathrm{D}$ used, and these companies had a lower probability to be financed by equity. As we posted before, a possible explanation for those differences could be due to the characteristics of capital markets in Colombia. In the case of Aghion et al. (2004), Minola \& Cassia (2013), and Audretsch \& Lehmann (2004), the size and liquidity of the U.K., U.S., and German markets can give access to firms for equity funding, therefore, the possibility of firms to replace debt for equity, when their ventures become larger or risky, can arise. However, in underdeveloped countries, firms could be equityconstrained given capital market characteristics.

Based on the late results, we can argue that in a country like Colombia, innovative firms will tend to finance their innovation ventures in the same way that POT predicts, i.e., firms will be highly supported on internal funding. However, if internal funding is not enough to support ventures, firms have to have access to bank debt, and in lower proportions, to other types of funds like equity, public grants, and others, with equity being the least used funding source.

Those results reinforce the fact that the financial behavior of innovative companies in a country like Colombia could be different than the behavior of companies in developed countries. In markets in which companies have deep and liquid markets, researchers tend to find APOT capital structures, but in our case, we found a POT structure. We believe that this result is caused by the impossibility of Colombian companies to use capital markets in order to finance innovation, given the low liquidity of this type of markets in this country. At the same time, our results show the necessity to design policies directed to overcome financial 
impediments of innovative firms in developed countries; however, we need to create those policies looking at the insights of our firms, instead of copying policies from other countries because firms are slightly different.

\section{CONCLUSIONS}

Reviewed researches about the capital structure of innovative and high technology firms seems to be contradictory. Some of those researches found that firms back up their R\&D and innovation activities as described by the pecking order theory (POT), however, some others found evidence of an Altered Pecking Order Theory (APOT) structure. However, given that researches with evidence related to the APOT have been developed in countries like United Kingdom, the United States, and Germany, and in some cases with publicly traded firms, we confronted those results founded in a context of developed capital markets against an underdeveloped country with small and illiquid capital markets like Colombia, and for non public firms.

We used the EDIT database for Colombia between 2007-2008, with 2.621 manufacturing firms with more than ten employees and with $\mathrm{R} \& \mathrm{D}$ expenditures. Given that we found significate correlations among the different types of sources used by these firms, we used a multivariate probit model to consider the simultaneity of the innovation funding phenomena.

Our results showed that the type of expenditures in which firms use their funds are essential to determine the financial sources used. Firms with internal funding are the ones expending on R\&D and intangible assets. We believe that firms investing in that type of assets face higher information asymmetries and have lower capabilities to provide guarantees to use external funding. In the case of bank funding, the loan guarantees are fundamental to the access to debt. We argue this because we found positive and significant relationships between bank funding and expenditure on tangible assets.

In the case of public grants, an expenditure patron similar to the ones using internal sources were found, i.e., firms using public grants were the ones expending on R\&D and intangible assets. We also found that intangible expenditures are related to equity funding, and it seems like firms with positive R\&D and intangible expenditures supported their ventures by using internal, equity, and public funding.

Our results seem to be related with literature showing that firm characteristics are determinant to the way innovative firms can have access to innovation funds (Bartoloni, 2013; Hummel et al., 2013; Minola et al., 2013; Ullah et al., 2010), however, this is not the case for internal funding, size, innovative behavior, or the perception of financial barriers, because they are not related with internal funding. Contrarily, the use of bank funding was strongly related with some firm characteristics. For instance, bigger firms and companies with a positive innovative behavior tended to have better access to bank funding; in the same direction, firms with a strong perception of financial barriers tended to use bank funding in higher proportions. As can be found in the literature, we related this late result to the fact that firms with higher perceptions of financial barriers had more experience in funding markets than other firms. At the same time, firms belonging to high technology industries seemed to be credit-constrained, i.e., there was a negative relationship between those industries and bank funding. We argue that market imperfections related to banks are stronger for firms in high technology industries. We also found that bigger firms are related to the use of public grants, and therefore, the funding gap between SMEs and big firms is being accentuated for public funding.

We found that innovation ventures in Colombia follow a Pecking Order capital structure, i.e. firms are strongly using internal funds, followed by banks, and then equity sources. However, the probability of firms using equity sources was lower than the probability of using government grants or other sources. To understand how some particular groups of firms have different likelihoods to access financial sources, we studied the success probabilities for firms using one or another funding source. We found that no matter how the samples were divided, firms were following a pecking order capital structure; however, we found that the 
probabilities for the use of internal sources were higher when firms had lower R\&D expenditures. Also, the probabilities for the use of bank funding were higher for those firms with upper R\&D expenditures.

Our results can be contrasted with the Aghion et al. (2004), Minola \& Cassia (2013), and Audretsch \& Lehmann (2004) research. Firms placed in countries like the United Kingdom, United States, or Germany, have higher access to equity funding given the characteristics of capital markets in those countries, and therefore, the possibility of firms replacing the debt for equity when their ventures become larger or risky can arise.

In order to successfully raise equity from markets, firms need to be supported by a liquid and specialized capital market to undertake an IPO, or to provide the necessary conditions for an exit strategy for an early venture capitalist (Hall \& Lerner, 2010; Kerr \& Nanda, 2015). However, in underdeveloped countries like Colombia, firms could be equity-constrained given that capital markets are in embryonic stages. Therefore, if internal funding is not enough to support ventures, firms have to access to bank debt, and in lower proportions, to other types of funding like public grants. The fact that firms with strong expenditures on intangible assets, seem to use equity in higher proportions, could be a sample of that singularity in developed countries, and that cannot be stronger in our case given the grade of development of Colombia's stock markets.

These results have strong policy implications; if innovative and high technology firms have problems financing their ventures externally, and in developed capital markets firms have easier access to high-risk equity, and venture capital, it is necessary for policymakers of underdeveloped countries to back up the expansion of strong and liquid capital markets in order to support the growth of innovative ventures; in the meantime, governments need to assure the provision of funds for R\&D\&i from debt markets and using public funding. At the same time, policymakers of underdeveloped countries, should not use policy designs used on developed countries, given that firm differences, but also, market differences, shape the way companies found their innovation ventures.

We believe that differences not only among companies, but also among capital markets within countries, are fundamental to understand the results of capital structures of innovative firms, because, in a country in which capital markets are deep and well organized, the APOT structure will arise as the result of market possibilities, but in countries with smaller and undeveloped markets, the POT structure will be more suited for industrial innovation. This research is a contribution to literature, because we propose that research results differences could be due to specific firm differences, but also due to differences in financial markets.

\section{Research limitations and future research}

Our research uses data from innovation surveys instead of using financial data from firms like is the habit in financial and innovation literature related to capital structure. This fact has its pros, and for example, we can assure that our results are deeply related to innovation activities, and we can guaranty that other factors related to operational, and financial day by day, are not affecting our results.

However, this fact also has cons. In first place, we would like to introduce some variables that are generally used by researches related with capital structure, for example, if the company is publicly traded or not, proprietary structure of the company, amounts of fixed capital on books, Tobin's Q., and so on; however, innovation surveys, do not have information about this variables, and particularly in the case of Colombia's survey, we are more restricted given that this is an anonymized survey.

At the same time, there are some questions that are asked usually on innovation surveys like, age of the firm, or amount of revenues related to innovation, that we cannot use given the secrecy of this survey. At the moment in which we perform our regressions, only data for the 2008-2009 survey was available; this does not allow us to perform panel regressions in order to understand if this was a permanent or temporal phenomenon. In the future, we want to develop more research about this topic using data from more recent 
years, and researching whether the development of financial markets is related to private R\&D expenditure of countries.

\section{Referencias}

Aghion, P., Bond, S., Klemm, A., \& Marinescu, I. (2004). Technology and Financial Structure: Are Innovative Firms Different? Journal of the European Economic Association, 2(2-3), 277-288. https://doi.org/10.1162/15424760 4323067989

Arundel, A. (1997). Enterprise strategies and barriers to innovation. Innovation Measurement and Policies. European Commission. (pp. 101-107). Recuperado de https://scholar.google.es/scholar?hl=es\&as_sdt=0\%2C5\&q=Ente rprise+strategies+and+barriers+to+innovation\&btnG=

Audretsch, D., \& Lehmann, E. (2004). Financing high-tech growth: The role of banks and venture capitalists. Schmalenbach Business Review, 56(4), 340-357. https://doi.org/10.1007/BF03396700

Baldwin, J., \& Lin, Z. (2002). Impediments to advanced technology adoption for Canadian manufacturers. Research Policy, v. 31. Recuperado de http://www.statcan.ca.

Bartoloni, E. (2013). Capital structure and innovation: causality and determinants. Empirica, 40(1), 111-151. https: //doi.org/10.1007/s10663-011-9179-y

Cappellari, L., \& Jenkins, S. P. (2003). Multivariate probit regression using simulated maximum likelihood. The Stata Journal, v. 3). Recuperado de https://journals.sagepub.com/doi/pdf/10.1177/1536867X0300300305

Colombo, M. G., \& Grilli, L. (2007). Funding Gaps? Access To Bank Loans By High-Tech Start-Ups. Small Business Economics, 29(1-2), 25-46. https://doi.org/10.1007/s11187-005-4067-0

D’Este, P., Iammarino, S., Savona, M., \& von Tunzelmann, N. (2012). What hampers innovation? Revealed barriers versus deterring barriers. Research Policy, 41(2), 482-488. https://doi.org/10.1016/J.RESPOL.2011.09.008

Freel, M. (2007). Are Small Innovators Credit Rationed? Small Business Economics, 28(1), 23-35. https://doi.org/1 $0.1007 / \mathrm{s} 11187-005-6058-6$

Giudici, G., \& Paleari, S. (2000). The Provision of Finance to Innovation: A Survey Conducted among Italian Technology-based Small Firms. Small Business Economics, 14(1), 37-53. https://doi.org/10.1023/A:10081874 16389

Hall, B., \& Lerner, J. (2009). The financing of R\&D and innovation. Handbook of the Economics of Innovation, I(1 C), 609-639. https://doi.org/10.1016/S0169-7218(10)01014-2

Hall, B. H., Moncada-Paternò-Castello, P., Montresor, S., \& Vezzani, A. (2016, abril 2). Financing constraints, R\&D investments and innovative performances: new empirical evidence at the firm level for Europe. Economics of Innovation and New Technology, 25(3), 183-196. https://doi.org/10.1080/10438599.2015.1076194

Hummel, D., Karcher, B., \& Schultz, C. (2013). The financial structure of innovative SMEs in Germany. Journal of Business Economics, 83(5), 471-503. https://doi.org/10.1007/s11573-013-0662-8

Iammarino, S., Sanna-Randaccio, F., \& Savona, M. (2009). The perception of obstacles to innovation. Foreign multinationals and domestic firms in Italy. Revue d'économie industrielle, 125, 75-104. https://doi.org/10.4000 $/$ rei.3953

Kraus, A., \& Litzenberger, R. H. (1973). A state-preference model of optimal financial leverage. The Journal of Finance, 28(4), 911-922. https://doi.org/10.1111/j.1540-6261.1973.tb01415.x

Manigart, S., \& Struyf, C. (1997). Financing High Technology Startups in Belgium: An Explorative Study. Small Business Economics, 9(2), 125-135. https://doi.org/10.1023/A:1007967722346

Mina, A., \& Lahr, H. (2018). The pecking order of innovation finance (No 31). Recuperado de http://www.lem.sssup .it/WPLem/files/2018-31.pdf

Minola, T., Cassia, L., \& Criaco, G. (2013, agosto 19). Financing Patterns in New Technology-Based Firms: An Extension of the Pecking Order Theory. Recuperado de https://papers.ssrn.com/sol3/papers.cfm?abstract_id=2 312648 
Modigliani, F., \& Miller, H. (1958). The Cost of Capital, Corporation Finance and the Theory of Investment. American Economic Review, v. 48.

Myers, S. (2001). Capital Structure. Journal of Economic Perspectives, 15(2), 81-102.

Myers, S., \& Majluf, N. (1984). Corporate financing and investment decisions when firms have information that investors do not have. Journal of Financial Economics, 13(2), 187-221. https://doi.org/10.1016/0304-405X(8 4) $90023-0$

OECD. (2005). Oslo Manual: Guidelines for Collecting and Interpreting Innovation Data. En Communities. https: //doi.org/10.1787/9789264013100-en

Sau, L. (2007). New Pecking Order Financing for Innovative Firms: an Overview, n. 3659. Recuperado de http://mp ra.ub.uni-muenchen.de/3659/

Schäfer, D., Werwatz, A., \& Zimmermann, V. (2004). The Determinants of Debt and (Private) Equity Financing: The Case of Young, Innovative SMEs from Germany. Industry \& Innovation, 11(3), 225-248. https://doi.org/10.1 080/1366271042000265393

Sierra González, J. H., Malaver Rodríguez, F., \& Vargas Pérez, M. (2009). La financiación de la Innovación: un análisis a partir de la Encuesta de Innovación de Bogotá y Cundinamarca. En Encuestas, datos y descubrimiento de conocimiento sobre la innovación en Colombia. Bogotá: Pontificia Universidad Javeriana.

Ullah, F., Abbas, Q., \& Akbar, S. (2010). The relevance of pecking order hypothesis for the financing of computer software and biotechnology small firms: some UK evidence. International Entrepreneurship and Management Journal, 6(3), 301-315. https://doi.org/10.1007/s11365-008-0105-0

\section{APPENDIX}

TABLE A1

High technology industries

\begin{tabular}{|l|l|l|}
\hline Industry description & ISIC Rev.3.1 & Number of firms \\
\hline $\begin{array}{l}\text { Manufacture of medical appliances and instruments and appliances for measuring, checking, testing, navigating } \\
\text { and other purposes, except optical instruments }\end{array}$ & 331 & 21 \\
\hline Manufacture of electric motors, generators and transformers & 17 \\
\hline Manufacture of electricity distribution and control apparatus & 311 & 16 \\
\hline Manufacture of other electrical equipment n.e.c. & 312 & 12 \\
\hline Manufacture of electric lamps and lighting equipment & 319 & 11 \\
\hline Manufacture of insulated wire and cable & 315 & 5 \\
\hline Manufacture of accumulators, primary cells and primary batteries & 313 & 5 \\
\hline Manufacture of electronic valves and tubes and other electronic components & 314 & 2 \\
\hline $\begin{array}{l}\text { Manufacture of television and radio receivers, sound or video recording or reproducing apparatus, and } \\
\text { associated goods }\end{array}$ & 321 & 323 \\
\hline Manufacture of optical instruments and photographic equipment & 332 \\
\hline Manufacture of aircraft and spacecraft & 353 & 2 \\
\hline Manufacture of television and radio transmitters and apparatus for line telephony and line telegraphy & 322 & 2 \\
\hline Total & 2 \\
\hline & 1 \\
\hline & $96(3.7 \%$ of the sample) \\
\hline
\end{tabular}

Source: EDIT 2007-2008.

\section{Notes}

* Artículo de investigación científica.

1 Manufacture industry survey for technologic development and innovation (Encuesta de desarrollo e innovación tecnológica de la industria manufacturera)

2 Includes cooperation, economic group, and other nonrelated firms funding.

\section{Licencia Creative Commons CC BY 4.0}

Cited as: Méndez-Morales, A. (2019). Show me the money: Pecking order and funding sources for innovative firms in Colombia. Cuadernos de Administración, 32(59). DOI: https://doi.org/10.11144/Javeriana.cao32 -59. stmpo 